\title{
Cement selection criteria for full coverage restorations: A comprehensive review of literature
}

\author{
Safoura Ghodsi ${ }^{1}$, Sarah Arzani ${ }^{2,3}$, Mina Shekarian ${ }^{2,3}$, MohammadMostafa Aghamohseni ${ }^{2,3}$
}

${ }^{1}$ Associate professor, Dental Research Center, Dentistry Research Institute, Department of Prosthodontics, Tehran University of Medical Sciences, Tehran, Iran

${ }^{2}$ Dentistry Student, Department of Prosthodontics, Isfahan (Khorasgan) Branch, Islamic Azad University, Isfahan, Iran

${ }^{3}$ Student Research Committee, Islamic Azad University, Isfahan (Khorasgan) Branch, Isfahan, Iran

Correspondence:

Department of Prosthodontics

School of Dentistry

Islamic Azad University of Isfahan (Khorasgan branch)

Isfahan, Iran

Postal code: 81551-39998

mm5656.aghamohseni@gmail.com

Received: 27/05/2021

Accepted: 24/08/202
Ghodsi S, Arzani S, Shekarian M, Aghamohseni MM. Cement selection criteria for full coverage restorations: A comprehensive review of literature. J Clin Exp Dent. 2021;13(11):e1154-61.

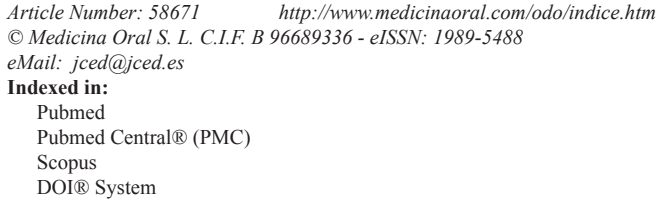

\begin{abstract}
Background: Proper cement selection in fixed prosthesis plays a determinative role in providing long-term serviceability, retention, caries prevention, and patient satisfaction. This study, reviews different luting agent characteristics and their application based on different clinical situations and different types of full coverage restorations.

Material and Methods: An electronic search was conducted through PubMed, Medline, and Google scholar using following keywords or combinations: restoration, full coverage, PFM, porcelain fused to metal, all ceramic, zirconia, ceramic, casting, fixed partial denture, cement*, dental cement, cement selection, and retention. The most related articles were selected for review.

Results: Choosing a proper luting agent is highly dependent on scientific knowledge regarding the characteristics of restorative materials and luting agents. Conventional cements could be indicated in various situations; however, some restorative materials or clinical situations call for resin-cements to provide predictable retention, support, and durability.

Conclusions: Conscious selection of retentive cement for each type of restoration/material is necessary to provide predictable successful treatment and reduce the potential complications.
\end{abstract}

Key words: Adhesive cement, dental bridgework, dental cements, dental crowns, dental porcelain, prostheses and implants.

\section{Introduction}

Full coverage restorations are among the most prevalent prosthetic treatments used in dentistry. This type of restoration could be indicated in varieties of conditions, ranged from heavily damaged, heavily restored, or cracked tooth to one with aesthetic or positional problems (1-3) and could be fabricated by different materials and methods. Full metal restorations (FM), the strongest and most durable type, has limited applications as more esthetic options have been improved to provide comparable durability, accuracy, and higher acceptance $(4,5)$. Porcelain fused to metal restorations (PFM), the gold standard of prosthetic care, provide acceptable mechanical and esthetic results (6). Rare adverse biological respond, and high long-term survival rate (mean of $75.5 \%$ over 20 years) (6-8), have made them the good 
candidates for restoring highly damaged teeth. However, esthetic appearance, caused by metal framework, overshadowed their applications in high-esthetic area (7). Full-ceramic restorations (FC), introduced less than five decades ago, are esthetic alternatives for PFM $(7,9)$. Good clinical results (survival rate of $74 \%$ over 104 months) (10) have candidate them as reliable options for clinical applications. The introduction of computer assisted design-computer assisted manufacturing (CADCAM) technology significantly improved the accuracy of prosthetic options and provided the chance of using new types of materials, namely different ceramics with improved characteristics, pre-polymerized resin composites blocks (11), hybrid ceramics, and different alloys. Single or multiunit tooth- or implant-supported full-coverage prostheses are among the most prevalent prosthetic treatments used in routine dental practices. Retention of indirect restorations, is the main single factor determines their survival and durability $(12,13)$. Although several factors like preparation design, abutment height and width, and surface macro and micro characteristics affect the retention, cementation is prerequisite of retentiveness in indirect restorations. Dental cement is basically used to fill the existing gap between the restoration and prepared tooth and prevent restoration dislodgment by mechanical interlocking $(14,15)$. Since several cementing materials are available today, choosing a proper cement could be confusing even for expert clinicians $(12,13,16)$. Dental cements are categorized in resin-based and acid-based materials $(15,17)$, each has its own characteristics, advantages, and indications (Table 1). Conscious selection of proper cement in each situation could positively affect the quality of long-term dental cares. The present study aimed to make a comprehensive review on available guidance for choosing a proper type of luting cement in each full-coverage restoration type and clinical situation.

\section{Material and Methods}

An electronic search was performed in PubMed, Medline, and Google scholar using following keyword or combinations: restoration, full coverage, PFM, porcelain fused to metal, all ceramic, zirconia, ceramic, casting, fixed partial denture, cement*, dental cement, selection, comparison, retention. The articles were selected from data bases as well as the related references of selected articles. Using reference management software (Endnote X9; Thomson Reuters), duplicated studies were eliminated. Afterwards, articles were selected based on title/abstract, and full text review. Two independent reviewers evaluated the studies and discussed to reach the same decision. In cases of disagreement, the third reviewer was asked to participate in decision. Peer-reviewed article focused on full-coverage restorations, different cements properties, and cement selection were included, while studies on other types of restorations were excluded, as well as case reports.

\section{Results}

Number of search results for the selected keywords was 8459 (PubMed), 10256 (Google scholar) and 6956 (Scopus). After duplicate removal and title/abstract analysis, 146 studies were selected for full-text review. Finally, 97 studies met the requirement of inclusion/exclusion criteria and were included to be discussed.

Dental cements have a long history. Zinc oxide eugenol (ZOE) was the first luting agent developed in $1850 \mathrm{~s}$ (18). Zinc phosphate cement was developed thirty years later, and glass ionomer cement was produced in 1972. In 2004 the last generation of luting agent, self-adhesive resin cements, was developed (18). Dental cements could be categorized based on their characteristics. Calcium hydroxide and ZOE cement are used as provisional cements (18). Main disadvantages of ZOE return to obtunding effect on dental pulp, high film thickness,

Table 1: Properties of dental cements. ZP: Zinc Phosphate, ZPC: Zinc Polycarboxylate, GI: Glass ionomer, RMGI: Resin modified glass ionomer, RC: resin cement.

\begin{tabular}{|l|c|c|c|c|c|c|c|c|}
\hline Luting cement & $\begin{array}{c}\text { Compressive } \\
\text { strength (MPa) }\end{array}$ & $\begin{array}{c}\text { Tensile } \\
\text { strength } \\
(\mathrm{MPa})\end{array}$ & $\begin{array}{c}\text { Setting } \\
\text { time } \\
(\mathrm{min})\end{array}$ & $\begin{array}{c}\text { Working } \\
\text { time (min) }\end{array}$ & $\begin{array}{c}\text { Tooth structure } \\
\text { bond }\end{array}$ & $\begin{array}{c}\text { Fluoride } \\
\text { release }\end{array}$ & $\begin{array}{c}\text { Pulpal } \\
\text { irritation }\end{array}$ & Solubility \\
\hline $\begin{array}{l}\text { Ideal material } \\
(21,37-39)\end{array}$ & High & High & Long & Short & Yes & Yes & Low & Low \\
\hline ZP $(15,18,21)$ & 98 & 6 & 8.6 & 3.75 & No & No & Moderate & High \\
\hline ZPC $(15,18,21)$ & 77 & 10 & 7.5 & 2.125 & Some & No & Low & High \\
\hline GI $(15,18,21)$ & 132.5 & 6.5 & 7.5 & 2.9 & chemical bond & Yes & High & Low \\
\hline RMGI $(15,18,21)$ & 98 & 18.5 & 2 & 3 & chemical bond & Yes & High & Very low \\
\hline RC $(21,34,21)$ & 209.75 & 35.5 & 8 & 2.75 & $\begin{array}{c}\text { micromechanical } \\
\text { bond }\end{array}$ & No & High & Very low \\
\hline
\end{tabular}


and inhibition effect on resin cements' polymerization $(19,20)$. Zinc phosphate, zinc polycarboxylate, glass-ionomer, resin-modified glass-ionomer, and resin cements are categorized as long-term definitive cements (20).

Zinc phosphate (ZP) cement is the oldest definitive cement introduced in 1800s, and has a wide range of applications $(15,18,21,22)$. ZP cement has the least biocompatibility $(12,21)$, and no chemical bond to tooth structure $(15,18)$. It has about $98 \mathrm{MPa}$ compressive strength, $6 \mathrm{MPa}$ tensile strength, $13 \mathrm{GPa}$ modulus of elasticity, and a high solubility $(0.28 \%)(15,18)$.

Zinc Polycarboxylate (ZPC) cement, introduced in 1968 (15), shows molecular adhesion to tooth structure by chemical and van der Waals bond $(15,21)$. ZPC has moderate compressive, and low tensile strength $(15,18)$, and lower solubility and pulpal irritation compared to ZP (15,21). Among the luting agents, ZPC shows the highest initial $\mathrm{PH}$, which results in the highest biocompatibility $(18,23)$.

Glass-ionomer (GI) cement or glass polyalkenoate was first introduced in 1969 (15). The ability of adhesion to tooth and base metal structure, thermal compatibility with enamel, low toxicity, and biocompatibility are among the advantages (24). GI cement has low solubility (21), and toughness (25). However, the most important advantage is fluoride releasing potential, with recharging capability in the oral environment that might play an effective role in caries prevention $(15,18)$.

Resin modified glass ionomer (RMGI) cement, the result of combining resin and GI (18), has improved moisture sensitivity, better mechanical properties, lower solubility, fluoride realizing capability, low translucency $(26,27)$, and the least post cementation sensitivity (28), RMGI cement has a dual mechanism of setting, acid-base reaction, and structural polymerization (18).

Resin cement (RC), the only true adhesive cement $(18,29)$, benefits from cement interlocking in addition to silanization-derived bonding (30). Very low solubility, similar translucency to tooth structure, and various color options have made it the cement of choice in esthetic restorations $(21,31)$. RC could be classified to etch-andrinse, self-etch, and self-adhesive RC. Etch-and rinse RC was introduced in 1990s, and consists of separate acid etching that is followed by priming/adhesive, and cement application $(32,33)$. This type is technique sensitive, however, provides reliable adhesion, and is the gold standard of adhesive bonding in dental practices $(34,31)$. Self-etch RC combined acid etching and priming in a self-etch primer (32). This type has less technical sensitivity, less dependence on the hydration state of dentin, acceptable dentine bonding (35), but lower enamel bonding strength ( $25 \%$ weaker) (32). Self-adhesive RC, on the other hand, has combined all the components in a single tube to facilitate the cementing procedure (36). A suitable long-term dental cement should have good biocompatibility, long working and short setting time, low film thickness, low solubility, caries prevention potential, chemical bond to tooth structure, an elastic modulus between tooth structure and restoration, plastic deformation resistance, and acceptable strength and toughness (21,37-39). Table 1 summarizes the properties of dental cements to facilitate the comparison.

\section{Discussion}

-General guidelines for cement selection: Selecting proper luting agents should be based on patient requirements, clinical situations, and the restorative material. Having enough information on cements will help the clinician to make a conscious choice; however, there are guidelines that could help to select appropriate cement in each situation: when access and moisture control are difficult to achieve, conventional cements are preferred over resin cements provided that acceptable retention and resistance form is achieved in preparation design (40). Resin cements should be used in partial coverage restorations such as inlays, onlays, and porcelain veneer restorations (41), and are routinely preferred in endodontically treated teeth $(42,43)$. or when reduced retention and resistance are expected in preparation design, height, or taper (40). Preparing the restorations for $\mathrm{RC}$ is more demanding since over etching, or over silanization might result in decreased bond strength (44). Different surface preparations with uncertain results or side effects have been suggested to increase resin bond strength for different material (45); however, all these procedures may not be applicable for daily practices in office settings. Resin cements application generally call for more skill, experience, and knowledge.

-The effect of restorative materials: a wide range of cement could be used for FM and PFM full coverage restorations. Conventional cements (ZP and GI) could be routinely used in normal single or multi-unit fixed prostheses (46). However, when the situation calls for increased retention (e.g. over-tapered or lower height preparation, long span fixed partial denture, cantilever application, parafunctional or diet habits, and in cases of offset loading on restoration), RMGI or RC could be indicated $(47,48)$. RMGI cement has been suggested as a preferred alternative for other conventional cements considering ease of use, strength, insolubility in mouth environment, and tooth bonding (47). When higher strength and retention are desired, self-curing self-adhesive or pre-encapsulated $\mathrm{RC}$ could be the cement of choice (40) with high reported survival rate $(49,50)$.

The important factor for cement selection in ceramic restorations is the composition and structure of ceramic material (41). Ceramic materials are divided into three main categories based on their composition: glass ceramics, polycrystalline (non-glass) ceramics, and hybrid ceramics (51). 
Glass ceramic has good esthetic, high biocompatibility, acceptable abrasion and fracture resistance (41), and low mechanical strength for their high glassy content $(41,52)$. Adhesive luting agents have been preferred for cementing these aesthetically appealing ceramics to increase their resistance to fracture (52). Etch-and-rinse type of RC provide higher bond strength, and more durable bonding $(37,38)$; however, other types of $\mathrm{RC}$ are also acceptable and well adequate for full coverage restorations (37-39). Conventional cements are contraindicated for this type of ceramics (53). Low glass ceramics, on the other hand, have acceptable esthetic and improved strength (41). Both adhesive or non-adhesive (conventional) cements could be used for cementing full-coverage restorations made from low glass ceramics $(54,55)$. Glass infiltrated ceramics, a branch of low-glass types, have the least glass content and the highest strength and fracture toughness (41). Conventional cements are preferred for this group as the application of acid hydrofluoric (HF) and adhesive bonding does not appear to increase the retention (56); however, RCs could also be used if indicated by clinical situations.

Polycrystalline ceramics are densely sintered oxide ceramics with no glassy content $(41,57)$. Their good resistance to propagation of cracks returns to regularly packed atoms in orderly arrays (58). Polycrystalline ceramics have high strength and toughness, and can be routinely used as frameworks (41) or full-contour restorations. Zirconia ( $\mathrm{ZrO} 2)$, the most well-known branch, was introduced in 1789 , and the first paper about its application was published in 1969 (59). Considering high fracture resistance and long-term survival rate, zirconia $(\mathrm{Zr})$ is the most prevalent non-metallic material in fixed prostheses (60). However, $\mathrm{Zr}$ shows some problem in adhesion to different substrates, and biomedical applications (60-62). Conventional cements are routinely indicated for full coverage zirconia restorations considering the simple and less demanding procedure. However, sometimes adhesive cements are indicated to achieve better marginal seal, and improved retention and fracture resistance $(41,45,60,63$ 67). In such cases, the application of air abrasion with aluminum oxide or tribochemical silica could effectively increase the bond strength by adhesive resins (68).

Hybrid ceramic were introduced to provide an ideal material with close elastic modulus to the remaining tooth structure while satisfy the esthetic appearance and durability of ceramic materials $(69,70)$. The new hybrid structure resulted in less fragility and superficial hardness that allow easier milling and promising clinical results (71). The evidences do not support using conventional cements in hybrid ceramics $(72,73)$. Resin cements seem to be the main cements of choice for this material $(72,73)$. However, very limited scientific evidences on the clinical success of these materials encourages further studies to be conducted (69).
Resin-composite has also been developed as indirect restorative material in CAD/CAM systems (74). They are less stiff compared to ceramics, that reduces wearing of opposing enamel and facilitates machining process by milling systems (74,75-78); A set of CAD/CAM burs could mill 5-10 ceramic crowns, while for resin-composite blocks this quantity reaches to over 100 crowns (79). Over the time, indirect composite materials have improved in their mechanical properties (66). A previous study showed that alumina airborne abrasion followed by silane and adhesive application could improve retention of resin-composite restorations $(80,81)$.

-Challenging situations call for increased retention: Some situations namely extensive destructive caries, abfraction, developmental anomalies, and short height of existing clinical crown are considered challenging for providing adequate retentive and resistance form in abutment teeth (82). The taper (optimal: 6 to 20 degrees) and geometry of prepared tooth as well as tooth surface area and condition, occlusal stresses, and luting agents are considered the main influencing factors in retention (82-84). Certain types of cements provide more retention compared to the others. Should the compromised situations call for increased retention, resin cements could be helpful. It has been reported ZP and GI provides the highest retention among conventional definitive cements, and ZPC shows the least (11).

-Cement selection in implant restorations: Fabrication of implant restorations needs a high degree of accuracy since small errors may lead to positional distortion and unfavorable stress on implants $(85,86)$. Although screw-retained restorations show some benefit in retrievability and biocompatibility, cement-retained types are among the prevalent choices for restoring missing teeth that facilitates obtaining passive fit, esthetic, and occlusal accuracy (87). Akca stated that temporary cement provides the least, ZPC provides intermediate, and GI and $\mathrm{ZP}$ cause the highest retention among conventional cement applicable in implant restorations (87), and Gultekin clarified that resin cements considerably stablishes the highest retention strength (84). However, considering the implant resistance to caries, temporary cements seem to provide acceptable retention beside the chance of retrieve ability for implant restorations in most clinical situations. Garg and et al., stated that Polycarboxylate cement showed the highest retention between Eugenol-free zinc oxide, resin-bonded, ZOE cement, zinc phosphate luting agents (86).

Selecting proper cement is the result of clinician information regarding available luting agents, and the restoration type/material, as well as the patients' clinical situations. It is mandatory for clinicians to consider the patient and treatment situation and choose the appropriate cement. Table 2 summarizes the results of available studies on different surface treatments and dental 
Table 2: Results of studies on dental cements and surface treatment effects on restorations retention. KHF2: Potassium hydrogen difluoride, RC: Resin cement, RMGI: Resin modified glass ionomer, ZP: Zinc Phosphate, GI: Glass ionomer.

\begin{tabular}{|c|c|c|c|c|}
\hline Reference & Restoration type & Cement type & Comparison & Conclusions \\
\hline $\begin{array}{c}\text { Kvam K, } 2019 \\
(88)\end{array}$ & $\begin{array}{c}\text { Single unit full } \\
\text { coverage- Zirconia }\end{array}$ & $\begin{array}{l}\text { self-curing resin-based } \\
\text { cement }\end{array}$ & $\begin{array}{l}\text { Surface preparation by } \\
\text { sandblasting, grinding } \\
\text { with carbide bur, and } \\
\text { melt-etching with KHF2 }\end{array}$ & $\begin{array}{c}\text { melt-etching with KHF2 } \\
\text { surface preparation caused } \\
\text { stronger bond than sandblast- } \\
\text { ed surface }\end{array}$ \\
\hline $\begin{array}{c}\text { Roy AK, } 2017 \\
\text { (89) }\end{array}$ & $\begin{array}{c}\text { Single unit full } \\
\text { coverage- Lithium } \\
\text { Disilicate }\end{array}$ & $\begin{array}{c}\text { self-adhesive vs. conven- } \\
\text { tional RC }\end{array}$ & $\begin{array}{l}\text { Cements' shear bond } \\
\text { strength }\end{array}$ & $\begin{array}{l}\text { Conventional RC showed } \\
\text { higher bond strength }\end{array}$ \\
\hline $\begin{array}{l}\text { Tomar SS, } \\
2015(90)\end{array}$ & $\begin{array}{l}\text { Single unit full } \\
\text { coverage- Full } \\
\text { metal }\end{array}$ & RMGI & $\begin{array}{l}\text { Sandblasting with } 110 \\
\mu \mathrm{m} \text { alumina and } 50 \mu \mathrm{m} \\
\text { alumina }\end{array}$ & $\begin{array}{l}110 \mu \mathrm{m} \text { alumina provided } \\
\text { significantly higher bond } \\
\text { strength }\end{array}$ \\
\hline $\begin{array}{l}\text { Jalandar SS, } \\
2012(91)\end{array}$ & $\begin{array}{l}\text { Single unit full } \\
\text { coverage- Full } \\
\text { metal }\end{array}$ & ZP, GI, RMGI & $\begin{array}{l}\text { The effect of desensitizing } \\
\text { agents (GLUMA and GC } \\
\text { tooth mouse) }\end{array}$ & $\begin{array}{l}\text { GLUMA had no effect on } \\
\text { crowns' retention } \\
\text { GC reduced the retention in } \\
\text { ZP, and had no effect on GI } \\
\text { and RMGI retentiveness }\end{array}$ \\
\hline $\begin{array}{l}\text { Reddy MR, } \\
2010(92)\end{array}$ & $\begin{array}{l}\text { Single unit full } \\
\text { coverage- Stain- } \\
\text { less steel }\end{array}$ & $\mathrm{ZP}$ and GI & Retention & $\begin{array}{c}\text { No significant difference was } \\
\text { observed }\end{array}$ \\
\hline $\begin{array}{c}\text { Ernst CP, } 2005 \\
\qquad(93)\end{array}$ & $\begin{array}{c}\text { Single unit full } \\
\text { coverage- Zirconia }\end{array}$ & $\begin{array}{l}\text { compomer-cement, GI, } \\
\text { RMGI, self-adhesive RC }\end{array}$ & Retention & $\begin{array}{l}\text { All groups had the same } \\
\text { retention }\end{array}$ \\
\hline $\begin{array}{l}\text { Blixt } M_{2} 2000 \\
\quad(94)\end{array}$ & $\begin{array}{l}\text { Procera aluminum } \\
\text { oxide coping ma- } \\
\text { terial Cylindric } \\
\text { and cubic speci- } \\
\text { mens }\end{array}$ & $\begin{array}{c}\text { ZP, GI, RMGI, dual cure } \\
\text { RC }\end{array}$ & $\begin{array}{l}\text { Shear bond strengths of } \\
\text { different cements on sand- } \\
\text { blasted surfaces }\end{array}$ & $\begin{array}{l}\text { No significant difference ob- } \\
\text { served in untreated surface. } \\
\text { GI had significantly higher } \\
\text { shear bond strength on sand- } \\
\text { blasted specimens }\end{array}$ \\
\hline $\begin{array}{l}\text { Shrivastav M, } \\
2018(95)\end{array}$ & $\begin{array}{l}\text { Implantsupported } \\
\text { nickel-chromium } \\
\text { bridge }\end{array}$ & $\mathrm{ZP}$ & $\begin{array}{l}\text { Surface treatment ef- } \\
\text { fect on retentiveness of } \\
\text { implantsupported bridge } \\
\text { with short abutments }\end{array}$ & $\begin{array}{l}\text { Groove+ bur modification } \\
\text { caused significantly higher } \\
\text { retention than groove+ sand- } \\
\text { blasting }\end{array}$ \\
\hline $\begin{array}{l}\text { Naumova EA, } \\
2018(96)\end{array}$ & $\begin{array}{l}\text { Cobalt-chromium } \\
\text { crowns }\end{array}$ & $\begin{array}{c}\text { Eugenol-free temporary } \\
\text { cement, composite- } \\
\text { based temporary ce- } \\
\text { ment, ZP, GI, RMGI }\end{array}$ & Retention force & $\begin{array}{l}\text { RMGI showed the highest } \\
\text { while eugenol-free tempo- } \\
\text { rary cement showed the least } \\
\text { bond strength }\end{array}$ \\
\hline $\begin{array}{l}\text { Güncü MB, } \\
2011(97)\end{array}$ & Metal crown & ZP, GI, eugenol free ZO & Retention force & $\begin{array}{l}\text { ZP exhibited higher reten- } \\
\text { tive force followed by GI and } \\
\text { eugenol free ZO }\end{array}$ \\
\hline
\end{tabular}

cement influence on the restorations' retention. The present review study attempted to summarize available data on cement selection in one of the most commonly used restorations in dental practices. Introduction of new materials for this type of restoration always call for extensive scientific evaluations to find the best and most effective cement material and ensure long-term clinical results. On the other hand, the evaluation of clinical effectiveness of available new cements specially in compromised or challenging situations requires further research, considering the ever-increasing application of full contour restorations.

\section{Conclusions}

Reviewing available articles concerning cement selection, the following conclusions can be made:

- Metallic and metal-ceramic full coverage restorations could be cemented by varieties of luting cements and proper cement selection is the result of evaluating tooth preparation, patient clinical situation, and special parafunctional or diet habits.

- Resin cements are indicated for high-glass ceramic restorations to provide reliable adhesive support, while low-glass and polycrystalline ceramics might be cemented by conventional luting agents. 
- Resin cements are the only cements indicated in hybrid ceramics.

- Resin cements could be used for full coverage restorations in case of need for increased retention.

\section{References}

1. Edelhoff D, Brix O. All-ceramic restorations in different indications: a case series. JADA. 2011;142:14S-9S

2. Christensen GJ. When is a full-crown restoration indicated? J Am Dent Assoc. 2007;138:101-3.

3. Carlsson GE. Success and failure of different types of crowns and fixed dental prostheses. J Pak Prosthodont Assoc. 2014;2:25-34.

4. Makhija SK, Lawson NC, Gilbert GH, Litaker MS, McClelland JA, Louis DR, et al. Dentist material selection for single-unit crowns: findings from the national dental practice-based research network. J Dent. 2016;55:40-70.

5. Rosenstiel SF, Land MF, Fujimoto J. Contemporary Fixed Prosthodontics. 4th ed. St. Louis, MO: Mosby Year Book; 2001; ch 8: 258271.

6. Daou EE. The zirconia ceramic: strengths and weaknesses. Open Dent J. 2014;8:33.

7. Canadian Agency for Drugs and Technologies in Health organization. Porcelain-fused-to-metal crowns versus all-ceramic crowns, 2015; available from https:/www.cadth.ca/sites/default/files/pdf/htis/ may-2015/RC0657\%20PFM\%20vs\%20Ceramic\%20Crowns\%20Final.pdf.

8. Näpänkangas R, Raustia A. Twenty-year follow-up of metal-ceramic single crowns: a retrospective study. Int J Prosthodont. 2008;21:307311.

9. Sailer I, Makarov NA, Thoma DS, Zwahlen M, Pjetursson BE. All-ceramic or metal-ceramic tooth-supported fixed dental prostheses (FDPs)? a systematic review of the survival and complication rates. Part I: Single crowns (SCs). Dent Mater J. 2015;31:603-23.

10. Toman M, Toksavul S. Clinical evaluation of 121 lithium disilicate all-ceramic crowns up to 9 years. Quintessence Int. 2015;46:189-197. 11. Silva LHD, Lima E, Miranda RBP, Favero SS, Lohbauer U, Cesar PF. Dental ceramics: a review of new materials and processing methods. Braz Oral Res. 2017;31:e58.

12. Pameijer C. A review of luting agents. Int J Dent. 2012;2012:752861. 13. Mitchell CA, Abbariki M, Orr JF. The influence of luting cement on the probabilities of survival and modes of failure of cast full-coverage crowns. Dent Mater J. 2000;16:198-206.

14. de la Macorra JC, Pradíes G. Conventional and adhesive luting cements. Clin Oral Investig. 2002;6:198-204.

15. Hill EE. Dental cements for definitive luting: a review and practical clinical considerations. Dent Clin North Am. 2007;51:643-58.

16. Simon JF, Darnell LA. Considerations for proper selection of dental cements. Compend Contin Educ Dent (Jamesburg, NJ: 1995). 2012;33:28-30.

17. Paul J. Dental cements-a Review to proper selection. Int J Curr Microbiol App Sci. 2015;4:659-9.

18. Carlsson GE. Success and failure of different types of crowns and fixed dental prostheses. J Pak Prosthodont Assoc. 2014;2:25-34.

19. Ribeiro JC, Coelho PG, Janal MN, Silva NR, Monteiro AJ, Fernandes $\mathrm{CA}$. The influence of temporary cements on dental adhesive systems for luting cementation. J Dent. 2011;39:255-62.

20. Erkut S, Küçükesmen HC, Eminkahyagil N, Imirzalioglu P, Karabulut ER. Influence of previous provisional cementation on the bond strength between two definitive resin-based luting and dentin bonding agents and human dentin. Oper Dent. 2007;32:84-93.

21. Rosenstiel SF, Land MF, Crispin BJ. Dental luting agents: a review of the current literature. J Prosthet Dent. 1998;80:280-301.

22. Pegoraro TA, da Silva NR, Carvalho RM. Cements for use in esthetic dentistry. Dent Clin N Am. 2007;51:453-71.

23. Charlton DG, Moore BK, Swartz ML. Direct surface pH determinations of setting cements. Oper Dent. 1991;16:231-8.

24. Lohbauer U. Dental glass ionomer cements as permanent fi- lling materials? properties, limitations and future trends. Materials. 2010;3:76-96.

25. Khoroushi M, Keshani F. A review of glass-ionomers: from conventional glass-ionomer to bioactive glass-ionomer. Dent Res J (Isfahan). 2013;10:411-420.

26. Manuja N, Pandit IK, Srivastava N, Gugnani N, Nagpal R. Comparative evaluation of shear bond strength of various esthetic restorative materials to dentin: an in vitro study. J Indian Soc Pedod Prev Dent. 2011;29:7-13.

27. Xu X, Burgess JO. Compressive strength, fluoride release and recharge of fluoride-releasing materials. Biomaterials. 2003;24:24512461.

28. Chandrasekhar V. Post cementation sensitivity evaluation of glass Ionomer, zinc phosphate and resin modified glass Ionomer luting cements under class II inlays: An in vivo comparative study. J Conserv Dent. 2010;13:23-7.

29. Burke FT. Resin Luting Materials. Dent Update. 2019;46:371-378. 30. Kameyama A, Bonroy K, Elsen C, LŘhrs AK, Suyama Y, Peumans $\mathrm{M}$, et al. Luting of CAD/CAM ceramic inlays: Direct composite versus dual-cure luting cement. Bio-Med Mater Eng. 2015;25:279-88. 31. Heboyan A, Vardanyan AR, Avetisyan AA. Cement selection in dental practice. World Science. 2019;3:4-9.

32. Sofan E, Sofan A, Palaia G, Tenore G, Romeo U, Migliau G. Classification review of dental adhesive systems: from the IV generation to the universal type. Ann Stomatol (Roma). 2017;8:1-17.

33. Deliperi S, Bardwell DN, Wegley C. Restoration interface microleakage using one total-etch and three self-etch adhesives. Oper Dent. 2007;32:179-84.

34. Peumans M, Kanumilli P, De Munck J, Van Landuyt K, Lambrechts P, Van Meerbeek B. Clinical effectiveness of contemporary adhesives: a systematic review of current clinical trials. Dent Mater J. 2005;21:864-81.

35. Perdigão J, Swift Jr EJ. Dentin/enamel bonding. J Esthet Restor Dent. 2010;22:82-5.

36. Radovic I, Monticelli F, Goracci C, Vulicevic ZR, Ferrari M. Self-adhesive resin cements: a literature review. J Adhes Dent. 2008; 10:251-258.

37. Lawson NC, Litaker MS, Ferracane JL, Gordan VV, Atlas AM, Rios T, Gilbert GH, et al. National Dental Practice-Based Research Network Collaborative Group. choice of cement for single-unit crowns: Findings from The National Dental Practice-Based Research Network. J Am Dent Assoc. 2019;150:522-30.

38. Jose C, Pradíes G. Conventional and adhesive luting cements. Clin Oral Investig. 2002;6:198-204.

39. Lia ZC, White SN. Mechanical properties of dental luting cements. J Prosthet Dent. 1999;81:597-609.

40. Hill EE, Lott J. A clinically focused discussion of luting materials. Aust Dent J. 2011;56:67-76.

41. Vargas MA, Bergeron C, Diaz-Arnold A. Cementing all-ceramic restorations: recommendations for success. J Am Dent Assoc. 2011;142:20S-4S.

42. Pegoraro TA, da Silva NR, Carvalho RM. Cements for use in esthetic dentistry. Dent Clin North Am. 2007;51:453-471.

43. Christensen GJ. Reducing the confusion about resin cements. Clin Rep. 2008;1:1-3.

44. Alex G. Preparing porcelain surfaces for optimal bonding. Compend Contin Educ Dent. 2008;29:324-336.

45. Blatz MB, Chiche G, Holst S, Sadan A. Influence of surface treatment and simulated aging on bond strengths of luting agents to zirconia. Quintessence Int. 2007;38:745-753.

46. Haddad MF, Rocha EP, Assunção WG. Cementation of prosthetic restorations: from conventional cementation to dental bonding concept. J Craniofac Surg. 2011;22:952-958.

47. Christensen GJ. Cementing porcelain-fused-to-metal crowns. J Am Dent Assoc. 1997;128:1165-7.

48. Ayad MF, Johnston WM, Rosenstiel SF. Influence of tooth preparation taper and cement type on recementation strength of complete metal crowns. J Prosthet Dent. 2009;102:354-61.

49. Brondani LP, Pereira-Cenci T, Wandsher VF, Pereira GK, Valandro 
LF, Bergoli CD. Longevity of metal-ceramic crowns cemented with self-adhesive resin cement: a prospective clinical study. Braz Oral Res. 2017;31:e22.

50. Lahori M, Nagrath R, Sisodia S, Dagar P. The effect of surface treatments on the bond strength of a nonprecious alloy-ceramic interface: an invitro study. J Indian Prosthodont Soc. 2014;14:151-5.

51. Gracis S, Thompson VP, Ferencz JL, Silva NR, Bonfante EA. A new classification system for all-ceramic and ceramic-like restorative materials. Int J Prosthodont. 2015;28:227-235.

52. Bottino MA, Salazar-Marocho SM, Leite FP, Vasquez VC, Valandro LF. Flexural strength of glass-infiltrated zirconia/alumina-based ceramics and feldspathic veneering porcelains. J Prosthodont. 2009; 18:417-20.

53. Blatz MB, Sadan A, Kern M. Resin-ceramic bonding: a review of the literature. J Prosthet Dent. 2003;89:268-274.

54. Fasbinder DJ, Dennison JB, Heys D, Neiva G. A clinical evaluation of chairside lithium disilicate $\mathrm{CAD} / \mathrm{CAM}$ crowns: a two-year report. J Am Dent Assoc. 2010;141:10S-4S.

55. Wolfart S, Eschbach S, Scherrer S, Kern M. Clinical outcome of three-unit lithium-disilicate glass-ceramic fixed dental prostheses: up to 8 years results. Dent Mater. 2009;25:e63-e71.

56. Al-Wahadni AM, Hussey DL, Grey N, Hatamleh MM. Fracture resistance of aluminium oxide and lithium disilicate-based crowns using different luting cements: an in vitro study. J Contemp Dent Pract. 2009;10:51-8.

57. Kelly JR. Dental ceramics: current thinking and trends. Dent Clin. 2004;48:513-30.

58. Guess PC, Zhang Y, Kim JW, Rekow ED, Thompson VP. Damage and reliability of Y-TZP after cementation surface treatment. J Dent Res. 2010;89:592-6.

59. Amat NF, Muchtar A, Yahaya N, Ghazali MJ. A review of zirconia as a dental restorative material. AJBAS. 2012;6:9-13.

60. Thompson JY, Stoner BR, Piascik JR, Smith R. Adhesion/cementation to zirconia and other non-silicate ceramics: where are we now? Dent Mater J. 2011;27:71-82.

61. Della Bona A, Kelly JR. The clinical success of all-ceramic restorations. J Am Dent Assoc. 2008;139:S8-13.

62. Kelly JR, Denry I. Stabilized zirconia as a structural ceramic: an overview. Dent Mater J. 2008;24:289-98.

63. Mattiello RDL, Coelho TMK, Insaurralde E, Coelho AAK, Terra GP, Kasuya AVB, et al. A Review of Surface Treatment Methods to Improve the Adhesive Cementation of Zirconia-Based Ceramics. ISRN Biomaterials. 2013;1-10.

64. Gargava S, Ram SM. Evaluation of Surface Conditioning of Zirconia and Its Effect on Bonding to Resin-Luting Agent. J Contemp Dent. 2013;3:7-10.

65. Thompson JY, Stoner BR, Piascik JR, Smith R. Adhesion/cementation to zirconia and other non-silicate ceramics: where are we now? Dent Mater J. 2011;27:71-82.

66. Blatz MB, Sadan A, Kern M. Resin-ceramic bonding: a review of the literature. J Prosthet Dent. 2003;89:268-74.

67. Blatz MB, Sadan A, Arch Jr GH, Lang BR. In vitro evaluation of long-term bonding of Procera AllCeram alumina restorations with a modified resin luting agent. J Prosthet Dent. 2003;89:381-7.

68. Researches O, Supervision T. The glossary of prosthodontic terms. J Prosthet Dent. 2005;94:10-92.

69. Jorquera G, Mahn E, Sanchez JP, Berrera S, Prado MJ, Stange VB. Hybrid Ceramics in Dentistry: A Literature Review. J Clin Res Dent. 2018;1:1-5.

70. Della Bona A, Corazza PH, Zhang Y. Characterization of a polymer-infiltrated ceramic-network material. Dent Mater J. 2014;30:564-9. 71. Coldea A, Swain MV, Thiel N. Mechanical properties of polymer-infiltrated-ceramic-network materials. Dent Mater J. 2013;29:41926.

72. Campos F, Almeida CS, Rippe MP, De Melo RM, Valandro LF, Bottino MA. Resin bonding to a hybrid ceramic: effects of surface treatments and aging. Oper Dent. 2016;41:171-8.

73. Spitznagel FA, Vuck A, Gierthmühlen PC, Blatz MB, Horvath SD.
Adhesive Bonding to Hybrid Materials: An Overview of Materials and Recommendations. Compend Contin Educ Dent. 2016;37:630-637.

74. Alamoush RA, Silikas N, Salim NA, Al-Nasrawi S, Satterthwaite JD. Effect of the composition of CAD/CAM composite blocks on mechanical properties. Biomed Res Int. 2018;2018:1-8

75. Barizon KT, Bergeron C, Vargas MA, Qian F, Cobb DS, Gratton DG, et al. Ceramic materials for porcelain veneers: part II. Effect of material, shade, and thickness on translucency. J Prosthet Dent. 2014;112:864-70.

76. Fasbinder DJ, Dennison JB, Heys D, Neiva G. A clinical evaluation of chairside lithium disilicate CAD/CAM crowns. J Am Dent Assoc. 2010;141:10S-4S.

77. Lebon N, Tapie L, Vennat E, Mawussi B. Influence of CAD/CAM tool and material on tool wear and roughness of dental prostheses after milling. J Prosthet Dent. 2015;114:236-47.

78. Giordano R. Materials for chairside CAD/CAM-produced restorations. J Am Dent Assoc. 2006;137:14S-21S.

79. Ruse ND, Sadoun MJ. Resin-composite blocks for dental CAD/ CAM applications. J Dent Res. 2014;93:1232-4.

80. Nejat AH, Lee J, Shah S, Lin CP, Kulkarni P, Chavali R, et al. Retention of CAD-CAM resin composite crowns following different bonding protocols. Am J Dent. 2018;31:97-102.

81. Banomyong D, Harnirattisai C, Burrow MF. Posterior resin composite restorations with or without resin-modified, glass-ionomer cement lining: a 1-year randomized, clinical trial. JICD. 2011;2:63-9.

82. Kent WA, Shillingburg Jr HT, Duncanson Jr MG. Taper of clinical preparations for cast restorations. Quintessence international (Berlin, Germany: 1985). 1988;19:339.

83. Ferracane JL. Placing dental composites-a stressful experience. Oper Dent. 2008;33:247-57.

84. Gultekin P, Gultekin BA, Aydin M, Yalcin S. Cement selection for implant-supported crowns fabricated with different luting space settings. J Prosthodont. 2013;22:112-9.

85. Mehl C, Harder S, Wolfart M, Kern M, Wolfart S. Retrievability of implant-retained crowns following cementation. Clin Oral Implants Res. 2008;19:1304-11.

86. Garg P, Gupta G, Prithviraj DR, et al: Retentiveness of various luting agents used with implant-supported prostheses: a preliminary in vitro study. Int J Prosthodont. 2013;26:82-84

87. Akca K, İplikçioğlu H, Çehreli MC. Comparison of uniaxial resistance forces of cements used with implant-supported crowns. Int J Oral Max Impl. 2002;17:536-42.

88. Kvam K, Irkayek A, Vangaeva E, El-Homsi F. Comparison of sandblasted, ground and melt-etched zirconia crowns regarding adhesion strength to resin cement. Biomaterial Investigations in Dentistry. 2019;6:1-5.

89. Roy AK, Mohan D, Sunith M, Mandokar RB, Suprasidh S, Rajan S. Comparison of Shear Bond Strengths of Conventional Resin Cement and Self-adhesive Resin Cement bonded to Lithium Disilicate: An in vitro Study. J Contemp Dent Pract. 2017;18:881-6.

90. Tomar SS, Bhattacharyya J, Ghosh S, Goel P, Das S, Chakarvarty $\mathrm{K}$. Comparative evaluation of bond strength of all-metal crowns with different luting agents after undergoing various modes of surface treatments: An in-vitro study. J Indian Prosthodont Soc. 2015;15:318-25.

91. Jalandar SS, Pandharinath DS, Arun K, Smita V. Comparison of effect of desensitizing agents on the retention of crowns cemented with luting agents: an in vitro study. J Adv Prosthodont. 2012;4:127-33.

92. Reddy MR, Reddy VS, Basappa N. A comparative study of retentive strengths of zinc phosphate, polycarboxylate and glass ionomer cements with stainless steel crowns-an in vitro study. J Indian Soc Pedod Prev Dent. 2010;28:245.

93. Ernst CP, Cohnen U, Stender E, Willershausen B. In vitro retentive strength of zirconium oxide ceramic crowns using different luting agents. J Prosthet Dent. 2005;93:551-8.

94. Blixt M, Adamczak E, Lindén LA, Odén A, Arvidson K. Bonding to densely sintered alumina surfaces: effect of sandblasting and silica coating on shear bond strength of luting cements. Int J Prosthodont. 2000;13:221-226. 
95. Shrivastav M. Effect of surface treatments on the retention of implant-supported cement-retained bridge with short abutments: An in vitro comparative evaluation. J Indian Prosthodont Soc. 2018;18:15460.

96. Naumova EA, Roth F, Geis B, Baulig C, Arnold WH, Piwowarczyk A. Influence of Luting Materials on the Retention of Cemented Implant-Supported Crowns: An In Vitro Study. Materials (Basel). 2018;11:1853.

97. Güncü MB, Çakan U, Canay Ş. Comparison of 3 Luting Agents on Retention of Implant-Supported Crowns on 2 Different Abutments. Implant Dentistry. 2011;20:349-353.

Conflict of interest

Non declared. 